\title{
PENERAPANINKUIRI TERBIMBING SEBAGAI UPAYA MENINGKATKAN AKTIVITAS DAN PRESTASI BELAJAR MAHASISWA POKOK BAHASAN ANALISIS VEKTOR DI STMIK STIKOM INDONESIA
}

\author{
Ni Wayan Suardiati Putri ${ }^{1}$, Ni Kadek Suryati ${ }^{2}$ \\ Program Studi Teknik Informatika STMIK STIKOM Indonesia \\ Email: suardiati.putri88@gmail.com,
}

\begin{abstract}
ABSTRAK
Penelitian ini bertujuan untuk mengetahui peningkatan aktivitas dan prestasi belajar siswa kelas $\mathrm{H}$, matakuliah matematika 1 di STMIK STIKOM Indonesia melalui penerapan pembelajaran inkuiri vektor pembelajaran terpandu. Penelitian ini menggunakan pendekatan kualitatif, jenis penelitian ini adalah Penelitian Tindakan Kelas oleh model Kurt Lewin. Subyek penelitian ini adalah siswa kelas H Matematika 1 di STMIK STIKOM Indonesia sebanyak 29 siswa. Berdasarkan hasil ini, dapat disimpulkan bahwa penerapan pembelajaran inkuiri terbimbing dapat meningkatkan aktivitas dan pencapaian pembelajaran analisis vektor. Hal ini ditunjukkan dengan peningkatan persentase aktivitas belajar siswa dari siklus I ke siklus II sebesar $25,56 \%$ dan persentase peningkatan nilai rata-rata siswa, ketuntasan belajar, serapan dari pra siklus ke siklus I masing-masing sebesar 9,188\%. 13,33\%, dan 9,18\%, dan persentase peningkatan nilai rata-rata siswa, penguasaan pembelajaran, dan penyerapan dari siklus I ke siklus II adalah 12,69\%, 41,19\% dan 12,69\%.
\end{abstract}

Kata kunci: penelitian kualitatif, inkuiri terbimbing, aktivitas siswa, prestasi belajar siswa

ABSTRACT

This study aims to determine the increase in activity and achievement of students of class $H$, mathematics course 1 in STMIK STIKOM Indonesia through the implementation of inquiry learning guided learning vector analysis. This research uses a qualitative approach, this kind of research is Classroom Action Research by model Kurt Lewin. The subjects of this study are the students of class H Mathematical subject 1 in STMIK STIKOM Indonesia as many as 29 students. Based on these results, it can be concluded that the application of guided inquiry learning can improve the activity and learning achievement of vector analysis. This is indicated by the increase in the percentage of student learning activities from the first cycle to the second cycle of $25.56 \%$ and the percentage increase in the average value of students, mastery learning, absorption from pre-cycle to the first cycle respectively $9.18 \% 13.33 \%$, and $9.18 \%$, and the percentage increase of the average value of students, learning mastery, and absorption from cycle I to cycle II were $12.69 \%, 41.19 \%$ and $12.69 \%$.

Keywords: qualitative research, guided inquiry, student activity, student achievement

\section{PENDAHULUAN}

Perkembangan pembelajaran

matematika di Indonesia sangat memprihatinkan, karena rendahnya penguasaan teknologi dan kemampuan sumber daya manusia Indonesia untuk berkompetensi secara global. Indonesia adalah sebuah negara dengan sumber daya alam yang melimpah. Namun masih rendahnya kemampuan anak Indonesia di bidang matematika, mereka beranggapan bahwa pembelajaran matematika itu sulit, Matematika dikenal sebagai ilmu dasar, pembelajaran matematika akan melatih kemampuan kritis, logis, analitis dan sistematis. Tetapi peran matematika tidak 
hanya sebatas hal tersebut, seperti bidang lain, ilmu komputer, ekonomi, biologi tidak terlepas dari peran matematika. Tetapi kemajuan ilmu komputer itu sendiri tidak akan tercapai tanpa peran penting matematika.

STMIK STIKOM Indonesia salah satu kampus ilmu komputer yang menerapkan matakuliah matematika sebagai mata kuliah wajib. Dari hasil observasi dosen dan mahasiswa pada mata kuliah matematika, ditemukan rendahnya nilai materi analisis vector, karena sulitnya mahasiswa dalam menganalisis vector dan mengaitkan kedalam kehidupan sehari-hari. Rendahnya nilai analisis vector juga berdampak pada rendahnya aktivitas mahasiswa dalam pembelajaran analisis vector.

Menurut Zaini (dalam Safitri, 2013) dikatakan bahwa "pembelajaran aktif adalah suatu pembelajaran yang mengajak peserta didik untuk belajar secara aktif". Ketika peserta didik belajar secara aktif, berarti mereka yang mendominasi aktivitas pembelajaran.Mahasiswa mengoptimalkan berfikir dengan baik untuk menemukan ide pokok, memecahkan persoalan atau mengaplikasikan ke dalam suatu persoalan yang ada dalam kehidupan nyata.

Salah satu pembelajaran yang mengedepankan mahasiswa aktif adalah pembelajaran inkuiri. Pembelajaran inkuiri adalah pembelajaran yang langkahnya mahasiswa merumuskan masalah, mendesain eksperimen, mengumpulkan dan menganalisis data sampai mengambil keputusan sendiri. Pembelajaran inkuiri harus memenuhi empat kriteria ialah kejelasan, kesesuaian, ketepatan dan kerumitannya. Mahasiswa benar-benar ditempatkan sebagai subjek yang belajar. Peranan dosen dalam pembelajaran dengan inkuiri adalah sebagai pembimbing dan fasilitator. Tugas dosen adalah memilih masalah yang perlu disampaikan kepada kelas untuk dipecahkan. Namun dimungkinkan juga bahwa masalah yang akan dipecahkan dipilih oleh mahasiswa.

Hal ini didukung oleh Sintaks pembelajaran inkuiri terbimbing menurut Triyanto (dalam Riyadi dkk, 2015) yaitu terdiri dari menyajikan masalah, membuat hipotesis, merancang percobaan, melakukan percobaan, menganalisis data, dan membuat kesimpulan. Dari sintak pembelajaran inkuiri tersebut memiliki potensi yang bermanfaat dalam meningkatkan keterampilan proses sains.menggunakan pembelajaran inkuiri terbimbing.

Berdasarkan latar belakang tersebut, maka peneliti tertarik mengadakan penelitian tindakan kelas dengan judul "Penerapan Inkuiri Terbimbing Sebagai Upaya Meningkatkan Aktivitas Dan Prestasi Belajar Mahasiswa Pokok Bahasan Analisis Vektor Di STMIK STIKOM Indonesia".

\section{METODE PENELITIAN}

Jenis penelitian yang dilaksanakan adalah penelitian tindakan kelas (Classroom Action Research). Subjek penelitian ini adalah mahasiswa semester ganjil yang mengambil mata kuliah matematika 1 yaitu kelas $\mathrm{H}$ dengan banyak mahasiswa 27 orang.

Model PTK yang digunakan dalam penelitian ini adalah model Kurt Lewin yang terdiri dari empat komponen yaitu perencanaan (planning), tindakan (acting), pengamatan (observing), dan (4) refleksi (reflecting) Hubungan keempat komponen tersebut dipandang sebagai satu siklus yang dapat digambarkan sebagai berikut. 


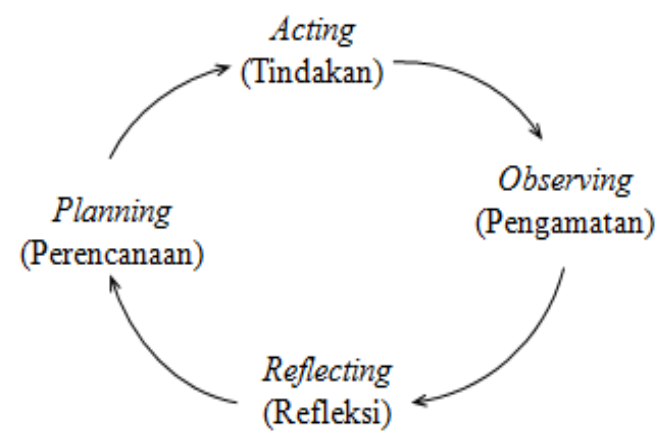

Gambar 1.PTK Model Kurt Lewin

(Diadopsi dari Depdiknas (dalam Putri, 2017)

\section{Data dan Teknik Pengumpulan Data}

Data yang dikumpulkan yaitu dengan mengumpulkan data aktivitas dan prestasi belajar matematika. Aktivitas belajar mahasiswa dikumpulkan dengan metode observasi dan data prestasi belajar mahasiswa dikumpulkan dengan menggunakan metode tes.

\section{Teknik Analisis Data}

Hasil perhitungan nilai rata-rata kelas, ketuntasan belajar (KB), dan Daya Serap (DS) selanjutnya dikomparasikan dengan standar acuan Depdikbud yaitu proses pembelajaran telah optimal apabila rata-rata nilai mahasiswa minimal 65 dan ketuntasan belajar dikatakan tercapai jika $\mathrm{KB} \geq 85 \%$ dan daya serap dikatakan tercapai jika DS $\geq 65 \%$. (Depdikbud dalam Putri, 2017)

\section{Prosedur Penelitian}

Penelitian ini dilaksanakan selama 2 siklus yang terdiri dari 4 komponen yaitu perencanaan, tindakan, observasi, dan refleksi.

\section{Refleksi Awal}

Seperti telah dikemukan sebelumnya, diketahui bahwa aktivitas dan prestasi belajar mahasiswa pada materi analisis vektor masih tergolong rendah. Hal ini diduga disebabkan oleh beberapa faktor yaitu, (1) masih sulitnya mahasiswa dalam menganalisis vector dan mengaitkan dengan kehidupan sehari-hari (2) aktivitas belajar masih rendah, (3) kurangnya interaksi antar mahasiswa dalam pembelajaran analisis vector.

Untuk meningkatkan aktivitas dan prestasi belajar mahasiswa dalam materi analisis vector, dosen bisa menerapkan pembelajaran inkuiri terbimbing. Dimana dengan pembelajaran inkuiri terbimbing aktivitas mahasiswa secara maksimal untuk mencari dan menemukan, artinya pembelajaran inkuiri menempatkan mahasiswa sebagai subjek belajar, sehingga nantinya mahasiswa menemukan sendiri inti dari materi pelajaran itu sendiri.

\section{Siklus I}

Siklus I membahas tentang pemahaman vector dan pembuktian operasi vektor. Siklus ini dilaksanakan dalam dua kali pertemuan dengan rincian satu kali pertemuan untuk pelaksanaan pembelajaran dan satu kali pertemuan untuk tes akhir siklus I.

\section{Perencanaan Tindakan}

Berdasarkan hasil refleksi awal, maka beberapa hal yang perlu dipersiapkan dalam penelitian tindakan kelas ini yaitu (1) menyiapkan Rencana Pembelajaran Semester (RPS), (2) menyiapkan Lembar Kerja Siswa (LKS) dengan model pembelajaran inkuiri, (3) menyiapkan tes prestasi belajar matematika siklus I berupa tes essay, (4) menyiapkan lembar observasi, dan (5) menyiapkan jurnal atau catatan harian.

\section{Pelaksanaan Tindakan}

Pada tahap pelaksanaan tindakan ini, dosen melakukan kegiatan belajar mengajar melalui Pembelajaran Inkuri Terbimbing.(1) Dosen memulai pembelajaran dengan menyampaikan pencapaian kompetensi yang diharapkan di akhir kegiatan pembelajaran. Dilanjutkan 
dengan mengajukan pertanyaan yang berkaitan dengan materi yang akan diajarkan untuk menggali pengetahuan awal mahasiswa.

Menginformasikan/menyampaikan kepada mahasiswa prosedur pembelajaran, materi dan langsung mempersiapkan kegiatan untuk perumusan masalah yang akan dipecahkan. (3) Dosen mengorganisasikan siswa dalam belajar dengan membagi siswa menjadi beberapa kelompok.

Mendorong/memotivasi mahasiswa merumuskan hipotesis serta meminta mahasiswa menuliskan hipotesis yang ada di papan tulis. (5) Memperkenalkan dan membagi LKS yang akan digunakan dalam menguji hipotesis. (6) Dosen memonitoring kegiatan uji hipotesis yang dilakukan mahasiswa sesuai dengan petunjuk yang ada di LKS. Kadang dosen memberikan bimbingan seperlunya kepada kelompok yang mengalami kesulitan dalam pengumpulan data. Meminta mahasiswa untuk mendiskusikan semua data yang terkumpul untuk dianalisis dan ditampilkan sebagai evaluasi dari hipotesis yang diajukan ditolak atau diterima. (7) Dosen memantau jalannya kegiatan diskusi dan memberi petunjuk bila diperlukan. Memfasilitasi mahasiswa untuk mempresentasikan hasil pengamatannya, memberikan kesempatan kepada kelompok untuk memberi tanggapan dari hasil presentasi kelompok lain dan memberikan reward terhadap kelompok yang melakukan presentasi dan kelompok yang memberikan tanggapan. (8) Reward yang berupa pujian atau penguatan yang diberikan dosen menjadi motivasi yang sangat berarti bagi perkembangan mental serta dapatmenumbuhkan rasa percaya diri terhadap kompetensi dalam diri mahasiswa.

\section{Observasi}

Kegiatan yang dilakukan pada tahap observasi dan evaluasi ini adalah sebagai berikut.Tahap observasi dilakukan saat kegiatan pembelajaran analisis melalui penerapan pembelajaran inkuri terbimbing berlangsung dengan mengamati aktivitas belajar mahasiswa yang ditulis pada lembar observasi.. Evaluasi dilakukan dengan memberikan tes akhir siklus yang dilaksanakan untuk mengetahui prestasi belajar mahasiswa setelah selesai mengikuti kegiatan pembelajaran melalui pembelajaran inkuiri terbimbing.

\section{Refleksi}

Refleksi ini dilakukan berdasarkan hasil observasi dan evaluasi, jadi untuk mengkaji kekurangan dan kendala dari tindakan yang telah dilaksanakan pada siklus I. Selain itu hasil refleksi dijadikan sebagai dasar atau pedoman untuk penyempurnaan terhadap perencanaan tindakan pada siklus I, sehingga kelemahan-kelemahan atau kendala yang terjadi pada siklus I tidak akan terulang lagi pada siklus II.

\section{Siklus II}

Siklus II membahas tentang penerapan operasi vector dalam kehidupan sehari-hari. Siklus ini dilaksanakan dalam dua kali pertemuan dengan rincian satu kali pertemuan untuk pelaksanaan pembelajaran dan satu kali pertemuan untuk tes akhir siklus II.Rancangan pada siklus II ini disusun berdasarkan hasil refleksi pada siklus I, serta dilakukan perbaikanperbaikan bila perlu. Langkah-langkah melaksanakan siklus II hampir sama dengan siklus I.

Apabila tidak terdapat kendala-kendala yang berarti serta proses pembelajaran telah optimal yaitu tercapainya rata-rata nilai mahasiswa, daya serap dan ketuntasan belajar minimal berturut-turut: " 65 ", " $65 \%$ ", dan " $85 \%$ ", maka akan dirumuskan 
rekomendasi penelitian ini dan siklus dihentikan, jika tidak maka akan dilakukan siklus berikutnya.

\section{HASIL DAN PEMBAHASAN}

Hasil Penelitian

Tabel 01. Hasil Analisis Data Aktivitas Belajar Siswa

\begin{tabular}{lll}
\hline Siklus & Rata-Rata Skor Aktivitas & Kategori \\
\hline I & 13,89 & Cukup Aktif \\
\hline II & 17,44 & Aktif \\
\hline
\end{tabular}

Tabel 02. Hasil Analisis Data Prestasi Belajar Siswa

\begin{tabular}{cccc}
\hline Siklus & $\begin{array}{c}\text { Rata-Rata Nilai Siswa } \\
(\mathbf{M})\end{array}$ & $\begin{array}{c}\text { Ketuntasan Belajar } \\
(\mathbf{K B})\end{array}$ & Daya Serap (DS) \\
\hline Prasiklus & 64,18 & $55,56 \%$ & $64,18 \%$ \\
\hline I & 70,07 & $62,96 \%$ & $70,07 \%$ \\
\hline II & 78,96 & $88,89 \%$ & $78,96 \%$ \\
\hline
\end{tabular}

Tabel 03. Rekapitulasi Hasil Analisis Data Aktivitas dan PrestasiBelajar Siswa

\begin{tabular}{lccccccc}
\hline \multirow{2}{*}{ Variabel } & \multicolumn{3}{c}{ Hasil Analisis Data } & \multicolumn{2}{c}{$\begin{array}{c}\text { Persentase } \\
\text { Peningkatan }\end{array}$} & \multicolumn{2}{c}{ Keterangan } \\
\cline { 2 - 8 } & $\begin{array}{c}\text { Pra } \\
\text { Siklus }\end{array}$ & $\begin{array}{c}\text { Siklus } \\
\text { I }\end{array}$ & $\begin{array}{c}\text { Siklus } \\
\text { II }\end{array}$ & 0 - I & I - II & 0 - I & I - II \\
\cline { 2 - 8 } $\begin{array}{l}\text { Aktivitas } \\
\text { Belajar }\end{array}$ & - & 13,89 & 17,44 & - & $25,56 \%$ & - & Meningkat \\
\hline $\begin{array}{l}\text { Rata-rata Nilai } \\
\text { Siswa (M) }\end{array}$ & 64,18 & 70,07 & 78,96 & $9,18 \%$ & $12,69 \%$ & Meningkat & Meningkat \\
\hline $\begin{array}{l}\text { Ketuntasan } \\
\text { Belajar } \\
\text { (KB) }\end{array}$ & $55,56 \%$ & $62,96 \%$ & $88,89 \%$ & $13,33 \%$ & $41,18 \%$ & Meningkat & Meningkat \\
\hline $\begin{array}{l}\text { Daya Serap } \\
\text { (DS) }\end{array}$ & $64,18 \%$ & $70,07 \%$ & $78,96 \%$ & $9,18 \%$ & $12,69 \%$ & Meningkat & Meningkat \\
\hline
\end{tabular}

Keterangan :

$\mathbf{0}=$ Prasiklus

$\mathbf{I}=$ Siklus $\mathbf{I}$

II $=$ Siklus II

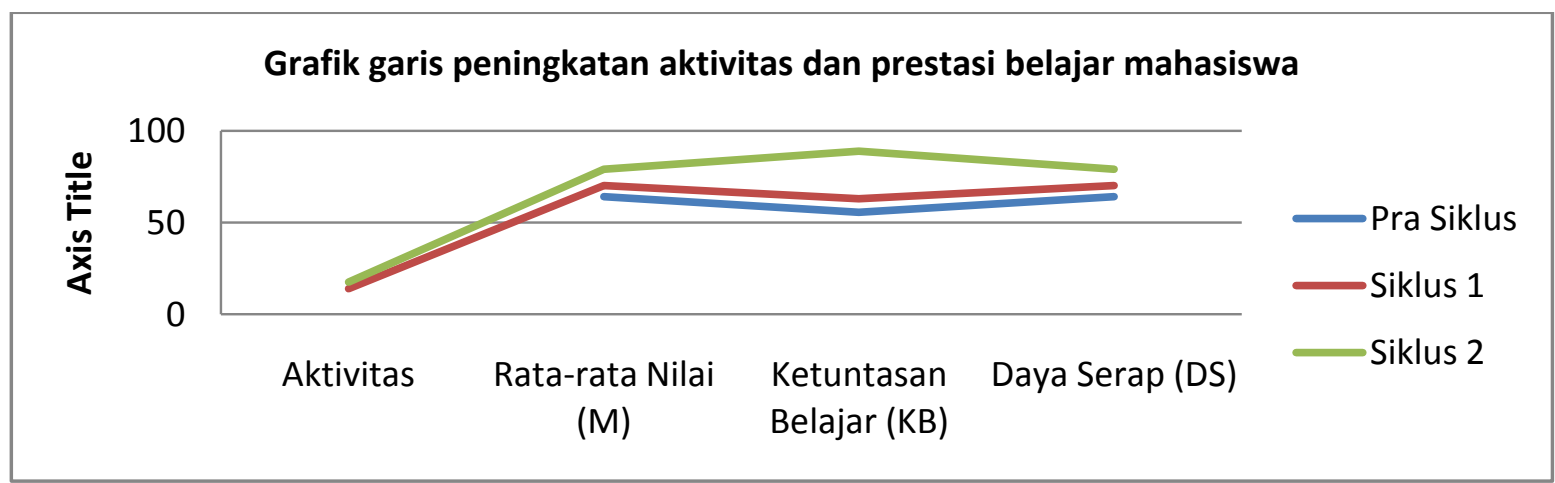

Grafik 01. Peningkatan aktivitas dan prestasi belajar mahasiswa 
Berdasarkan hasil analisis data yang diperoleh dari hasil tes prasiklus di dapat informasi tentang prestasi belajar mahasiswa pada pelajaran analisis vektor belum mencapai hasil yang optimal. Hal ini dapat dilihat rata-rata nilai siswa (M), ketuntasan belajar (KB) dan daya serap (DS) berturut-turut adalah 64,18, 55,56\%, dan $64,18 \%$. Hal ini menunjukkan prestasi belajar mahasiswa yang diperoleh selama mengikuti proses pembelajaran dalam pelajaran analisis vektor masih rendah. Pada tahap prasiklus ini tidak dilakukan observasi awal terhadap aktivitas belajar siswa. Berdasarkan hal tersebut maka peneliti melakukan penelitian tindakan kelas dengan menerapkan pembelajaran inkuiri terbimbing sebagai salah satu upaya untuk memperbaiki pembelajaran di kelas H Matematika 1STMIK STIKOM Indonesia.

Hasil analisis data prestasi belajar siswa pada siklus I diperoleh bahwa ratarata nilai (M), ketuntasan belajar (KB) dan daya serap (DS) berturut-turut adalah $70,07, \quad 62,96 \%$, dan 70,07\%. Jika dibandingkan dengan hasil prasiklus yang diperoleh dari tes awal maka persentase peningkatan rata-rata nilai (M), ketuntasan belajar (KB), dan daya serap (DS) dari pra siklus ke siklus I berturut-turut sebesar 9,18\%, 13,33\%, dan 9,18\%. Dari hasil analisis data aktivitas belajar diketahui bahwa rata-rata skor aktivitas belajar pada siklus I yaitu 13,89 dengan kategori “cukup aktif”. Walaupun telah terjadi peningkatan prestasi belajar siswa dari prasiklus ke siklus I, namun pembelajaran belum mencapai kriteria keberhasilan minimal yaitu minimal kategori "aktif", rata-rata nilai siswa $(\mathrm{M}) \geq 6,5$, ketuntasan belajar $(\mathrm{KB}) \geq 85,00 \%$ dan daya serap $(\mathrm{DS}) \geq$ $65,00 \%$.
Karena hasil pelaksanaan tindakan pada siklus I belum optimal, maka peneliti bersama teman sejawat melakukan refleksi terhadap pelaksanaan tindakan pada siklus I. Dari hasil refleksi dan catatan lapangan diperoleh bahwa kurang optimalnya pembelajaran pada siklus I oleh beberapa hal diantaranya: (1) siswa kesulitan merumuskan hipotesis,(2) ketua kelompok mendominasi dalam melakukan presentasi sehingga anggota kelompok yang lainnya belum mendapatkan kesempatan secara merata, (3) mahasiswa kesulitan dalam dalam mengambil kesimpulan dari hasil pengamatan, (3) aktivitas dosen belum terlaksana dengan maksimal, karena masih menyesuaikan dengan penerapan model pembelajaran inkuiri terbimbing, (4) penggunaan waktu belum efektif, belum sesuai dengan rencana pembelajaran, Ini menyebabkan pelaksanaan pembelajaran menjadi kurang maksimal.

Adapun foto kegiatannya sebagai berikut:
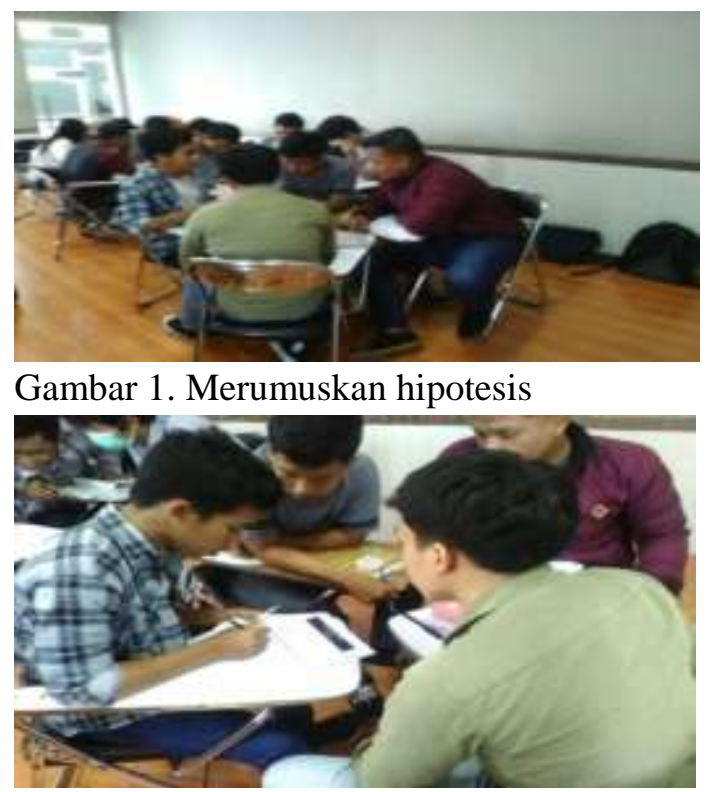

Gambar 2. Diskusi Kelompok 


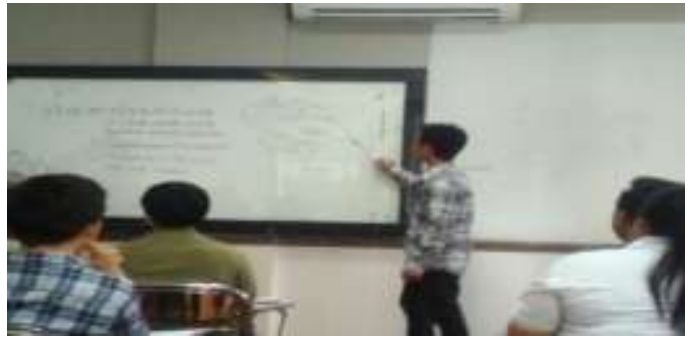

Gambar 3. Mempresentasikan hasil diskusi

Dari hasil refleksi, maka perlu dilakukan penyempurnaan pelaksanaan tindakan pada siklus II, yaitu (1)dosen menuntun mahasiswa agar tidak kesulitan merumuskan hipotesis, (2) dosen menunjukmahasiswa

kelompoknya dalam melakukan demonstrasi di depan kelas sehingga tidak didominasi oleh ketua kelompok, (4) dosen memotivasimaha siswa mengenai pentingnya pembagian tugas dan kerjasama antar anggota kelompok, dan (5) dosen menjelaskan langkah-langkah pembelajaran ke mahasiswa sehingga pembelajaran dapat berlangsung lebih efektif.

Dari pelaksanaan tindakan siklus II dan dari hasil observasi diperoleh hal-hal sebagai berikut: (1) mahasiswa mulai aktif dalam proses pembelajaran analisis vektor, (2) mahasiswa pandai tidak lagi mendominasi dalam menjawab pertanyaan dosen, (3) setiap anggota kelompok sudah terbiasa dalam melakukan kerjasama serta pembagian tugas sehingga pada saat kegiatan demonstrasi setiap kelompok terlihat kompak, (4) mahasiswa sudah bisa dalam menerapkan konsep vector dalam kehidupan sehari-hari. .Pada siklus II hasil analisis data prestasi belajar mahasiswa diperoleh bahwa rata-rata nilai $(\mathrm{M})=$ 78,96 , ketuntasan belajar $(\mathrm{KB})=88,89 \%$, dan daya serap $(\mathrm{DS})=78,96 \%$. Jika dibandingkan dengan hasil analisis data prestasi belajar pada siklus I, juga nampak terjadi peningkatan dengan persentase peningkatan rata-rata nilai (M) sebesar
12,69\%, ketuntasan belajar (KB)sebesar $41,19 \%$ dan daya serap (DS) sebesar $12,69 \%$.

Hasil analisis data aktivitas belajar mahasiswa diketahui bahwa rata-rata skor aktivitas belajar yaitu 17,44 dengan kategori "aktif". Jika dibandingkan dengan hasil analisis data aktivitas belajar pada siklus I, nampak terjadi peningkatan dengan persentase peningkatan skor aktivitas belajar dari siklus I ke siklus II sebesar $25,56 \%$.

Dari penyempurnaan pelaksanaan tindakan pada siklus I telah menunjukkan adanya peningkatan dalam pelaksanaan tindakan siklus II, diantaranya: (1)mahasiswa sudah mulai bisa merapkan konsep vector dalam kehidupan sehari-hari, (2) mahasiswa sudah berani melakukan demonstrasi di depan kelas dan tidak tergantung pada ketua kelompok, (3) kerjasama antar anggota kelompok lebih kompak, dan (4) suasana kelas lebih tertib sehingga pembelajaran berlangsung kondusif dan lebih efektif.

Pembelajaran dikatakan optimal apabila aktivitas belajar telah mencapai minimal kategori "aktif", rata-rata nilai (M) $\geq 65$, ketuntasan belajar $(\mathrm{KB}) \geq 85,00 \%$ dan daya serap (DS) $\geq 65,00 \%$. Dari hasil analisis data yang diperoleh pada siklus II, maka pembelajaran pada siklus II telah optimal karena memenuhi kriteria pembelajaran minimal yang telah ditetapkan, sehingga penelitian ini dihentikan sampai pada siklus II.

Karena aktivitas belajar dari siklus I ke siklus II telah mencapai kategori "aktif" dengan persentase peningkatan aktivitas belajar siswa sebesar $25,56 \%$ dan hasil prestasi belajar pada prasiklus, siklus I dan siklus II telah memenuhi pembelajaran yang optimal maka penelitian dihentikan sampai siklus II. Sehingga pelaksanaan 
Penelitian Tindakan Kelas yang bertujuan untuk mengetahui peningkatan aktivitas dan prestasi belajar mahasiswa dalam pembelajaran analisis vektor dengan menerapkan pembelajatan inkuiri terbimbingdi STMIK STIKOM Indonesia dapat dikategorikan berhasil.

\section{PENUTUP}

\section{Simpulan}

Berdasarkan hasil analisis data dan pembahasan, maka dapat disimpulkan sebagai berikut.

1. Terjadinya peningkatan aktivitas belajar mahasiswa kelas $\mathrm{H}$, matakuliah Matematika 1di STMIK STIKOM Indonesia dengan diterapkankannya pembelajaran inkuiri terbimbing dalam pembelajaran analisis vektor. Hal ini ditunjukkan oleh adanya peningkatan persentase aktivitas belajar mahasiswa dari siklus I ke siklus II sebesar 25,56\%.

2. Terjadi peningkatan prestasi belajar mahasiswa kelas $\mathrm{H}$, matakuliah Matematika 1di STMIK STIKOM Indonesia, dengan diterapkannya pembelajaran inkuiri terbimbing dalam pembelajaran analisis vektor. Hal ini ditunjukkan oleh adanya persentase peningkatan rata-rata nilai, ketuntasan belajar, dan daya serap siswa dari pra siklus ke siklus I berturut-turut sebesar $9,18 \%, \quad 13,33 \%$, dan 9,18\%, dan persentase peningkatan rata-rata nilai, ketuntasan belajar, dan daya serap siswa dari siklus I ke siklus II berturut-turut sebesar $12,69 \%, 41,19 \%$ dan 12,69\%.

\section{Saran}

Berdasarkan simpulan tersebut di atas, maka saran yang dapat diutarakan adalah sebagai berikut.

1. Kepada Dosen pengampu matakuliah Matematika 1 disarankan menerapkan pembelajaran Inkuiri Terbimbing sebagai salah satu alternative dalam pembelajaran matematika karena terbukti dapat meningkatkan aktivitas dan prestasi belajar mahasiswa.

2. Kepada peneliti lain, diharapkan untuk senantiasa melakukan penelitian lebih lanjut tentang pembelajaran Inkuiri Terbimbing dalam pembelajaran matematika.

\section{DAFTAR PUSTAKA}

Putri, N.W.S. (2017).Implementasi Strategi Pembelajaran Tandur Sebagai Upaya Meningkatkan Aktivitas Dan Prestasi Belajarsiswa Kelas Ii Sd Negeri 1 Singapadu Tengah Pada Pembelajaran Bangun Datar. Jurnal Santiaji Pendidikan, Volume 7, Nomor 1, Januari 2017ISSN 2087-9016.

ojs.unmas.ac.id/index.php/JSP/artic le/download/797/742

Riyadi, I.P dkk. (2015). Penerapan Model Pembelajaran Inkuiri Terbimbing (Guided Inquiry) pada Materi Sistem Koordinasi untuk Meningkatkan Keterampilan Proses Sains pada Siswa Kelas XI IPA 3 SMA Batik 2 Surakarta Tahun Pelajaran 2013/2014. Jurnal Jurnal Pendidikan Biologi Volume 7, Nomor 2, Halaman 80-93. https://media.neliti.com/media/publ ications/119339-ID-none.pdf

Safitri, M.R.I. (2013). Upaya Meningkatkan Aktivitas Dan Hasil Belajar Matematika Siswa Dengan Menggunakan Pembelajaran Kooperatif Tipe Cooperative Integrated Reading And Composition Pada Siswa Kelas Vii B Smp Taman Dewasa Ibu Pawiyatan Yogyakarta. Jurnal Pendidikan Matematika, Vol 1 No 1, November 2013. http://docplayer.info/59313579Union-jurnal-pendidikan- 
matematika-vol-1-no-1-november-

2013.html 